\title{
NATIONAL POLICY AND THE "PUBLIC INTEREST" -A MARRIAGE OF NECESSITY IN THE COMMUNICATIONS ACT OF 1934
}

The Communications Act of 1934 provides that before the Federal Communications Commission can grant a renewal of a broadcasting license, the Commission must find that the "public interest, convenience, and necessity" will be served thereby. ${ }^{1}$ This is the only standard which the Commission must apply in granting, renewing or modifying licenses, and Congress made no attempt, either in the "definitions" section of the act ${ }^{2}$ or in the legislative history, to establish further guidelines for the construction of the phrase "public interest, convenience, and necessity." Thus it has been for the FCC and the courts to formulate a reasonable definition. No concrete definition has ever been formulated.

The first significant case to comment on the "public interest" standard, Federal Radio Comm'n v. Nelson Bros. Bond \& Mortgage Co., ${ }^{3}$ stated that the standard is not so indefinite as to grant the Commission an unlimited power. ${ }^{4}$ Nonetheless, it is unclear what restraints the courts have placed on the power of the Commission. In McClatchy Broadcasting Co. v. FCC, ${ }^{5}$ Judge Miller stated that the standard does not lend itself to a "precise or comprehensive definition." ${ }^{6} \mathrm{He}$ went on to say that the only restrictions the court would place on the Commission were that the Commission must act neither arbitrarily nor capriciously and that it must act within statutory and constitutional bounds. ${ }^{7}$ That an agency must act within constitutional limits is obvious. For a court to say that the Commission must be neither arbitrary nor capricious and that it must act within statutory bounds is not particularly illuminating.

The District of Columbia Circuit was not always so vague. In WOKO, Inc. v. FCC, ${ }^{8}$ which preceded McClatchy by some ten years, the

148 Stat. 1085 (1934), as amended, 47 U.S.C. $\$ 309$ (a) (1964).

248 Stat. 1065 (1934), as amended, 47 U.S.C. \$153 (1964).

3289 U.S. 266 (1933). Nelson was decided under the Federal Radio Act, from which the "public interest" standard was adopted. S. REP. No. 781, 73d Cong., 2d Sess. 6-7 (1934).

4289 U.S. at 285 ; accord, Yankee Network, Inc. v. FCC, 107 F.2d 212, 219 (D.C. Cir. 1939) ; Pottsville Broadcasting Co. v. FCC, 105 F.2d 36, 40 (D.C. Cir. 1939), rev'd on other grounds, 309 U.S. 134 (1940).

5239 F.2d 15 (D.C. Cir. 1956), cert. denied, 353 U.S. 918 (1957).

"Id. at 18. This language is typical of that found in "public interest" cases. See, e.g., National Broadcasting Co. v. FCC, 319 U.S. 190, 216 (1943) (Frankfurter, J.); American Broadcasting Co. v. FCC, 191 F.2d 492, 497 (D.C. Cir. 1951).

7239 F.2d at 18.

8153 F.2d 623 (D.C. Cir. 1946). 
court overruled an FCC holding that because of a misstatement made in the station's application a renewal of WOKO's license would not be in the "public interest." The court felt that the FCC had abused its discretion, deeming the misstatement not so significant as to disqualify the applicant under the "public interest" standard. The Commission appealed to the Supreme Court, which reversed. ${ }^{9}$ The FCC's primary argument before the Court was that "a 'sensible exercise' of administrative judgment in applying statutory criteria of such breadth is to be left undisturbed. . . ."10 Agreeing, the Supreme Court held that there had been no abuse of discretion and that it was for the Commission rather than the courts to be satisfied that the granting of a renewal would be in the "public interest." 11

Thus for the most part "public interest" is an undefined and undefinable phrase and the FCC can interpret the standard as it pleases. Perhaps for the mine run of cases, this is as it should be, since it allows the Commission to bring its expertise and experience to bear on the facts of each particular case. ${ }^{12}$ The reasons generally advanced for leaving this kind of definition to the expertise and experience of the Commission are that the Commission has greater knowledge of the area and is more specialized in treating the problems that arise. ${ }^{13}$ These considerations do not apply, however, when a national policy has been clearly enunciated either by Congress or the courts-when either has prescribed unequivocally a course of action for the nation to follow. Since in such instances no expertise is necessary, ${ }^{14}$ the courts should make specific demands of the Commission.

That national policy is relevant to any consideration of "public interest" was first expressed in McLean Trucking Co. v. United States. ${ }^{15}$ Conflicting national policies bore on that case, as the Interstate Commerce Act authorized the ICC to approve mergers that "will be consistent with the public interest" ${ }^{16}$ and yet as a general rule, mergers were disfavored by the anti-trust laws. The Supreme Court held that the anti-trust laws should be a consideration, weighed in light of the overall transportation policy. ${ }^{17}$

9 FCC v. WOKO, Inc., 329 U.S. 223 (1946).

10 Brief for Appellant, p. 40, FCC v. WOKO, Inc., 329 U.S. 223 (1946).

$11 \mathrm{Id}$. at 229; see Harbenito Broadcasting Co. v. FCC, 218 F.2d 28, 33 (D.C. Cir. 1954).

12 See, e.g., FCC v. Pottsville Broadcasting Co., 309 U.S. 134 (1940) ; American Broadcasting Co. v. FCC, 191 F.2d 492, 498 (D.C. Cir. 1951).

13 See, e.g., NLRB v. Hearst Publications, Inc., 322 U.S. 111, 130 (1944); Gray v. Powell, 314 U.S. 402, 412 (1941).

14 See James S. Rivers, Inc. (WJAZ) v. FCC, 351 F.2d 194, 198 (D.C. Cir. 1965) (Bazelon, C.J., concurring); $c f$. SEC v. Chenery Corp., 318 U.S. 80, 94 (1943).

15321 U.S. 67 (1944). In this case, the phrase "public interest" was contained in $\$ 7$ of the Interstate Commerce Act, 54 Stat. 906 (1940), as amended, 49 U.S.C. \$ (2) (b) (1964).

1654 Stat. 906 (1940), as amended, 49 U.S.C. $\$ 5(2)$ (b) (1964).

17321 U.S. at 87. 
The relationship between national policy and "public interest" was also the primary issue in $F C C$ v. RCA Communications, Inc., ${ }^{18}$ in which the FCC allowed Mackay Radio and Telegraph Company to compete with RCA in the sphere of international communications. The Commission stated that it had an affirmative duty to consider the national policy favoring competition..$^{10}$ The court of appeals reversed, holding that the FCC had not found that any benefits would accrue to the public from the granting of the modification. ${ }^{20}$ The Supreme Court vacated the judgment of the court of appeals and remanded the case to that court with instructions to remand to the Commission for further consideration. ${ }^{21}$ The chief reason for the Supreme Court's decision seems to have been that the Commission was misguided in finding a national policy favoring competition. ${ }^{22}$ It is implicit in Mr. Justice Frankfurter's opinion, nonetheless, that if the Court had felt that there was such a national policy, the decision of the FCC would have been upheld. ${ }^{23}$

National policy is therefore a relevant consideration in determining the "public interest." That this is not enough-that national policy should not be merely relevant but rather controlling when that policy is clearly enunciated and critically important-is suggested by consideration of the recent FCC decision in Lamar Life Broadcasting Co. ${ }^{24}$

In Lamar, a Jackson, Mississippi, television station applied for renewal of its license. The United Church of Christ filed a petition to deny the renewal. The Commission noted, consistent with its past holdings, that United Church did not have standing before it. Also consistent with its past procedure, however, the Commission stated that it would consider the points raised by United Church's petition. ${ }^{25}$ In its petition United Church alleged ${ }^{26}$ that the station, WLBT, had been attempting to frustrate the national policy favoring racial equality. ${ }^{27}$ Moreover the FCC found upon its own investigation that WLBT had broadcast prosegregation editorials

18346 U.S. 86 (1953).

19 Mackay Radio \& Tel. Co., 5 Radio Reg. 561, 583 (FCC 1951).

20 RCA Communications, Inc. v. FCC, 201 F.2d 694, 698 (D.C. Cir. 1952).

21 FCC v. RCA Communications, Inc., 346 U.S. 86, 98 (1953).

22 Id. at 96 . Mr. Justice Frankfurter said that "the conclusion [that the granting of a modification would be in the public interest] was not based on the Commission's own judgment but rather on the unjustified assumption that it was Congress' judgment that such authorizations are desirable. . . ."

$23 \mathrm{On}$ remand, the Commission arrived at the same decision it had previously reached, but without the aid of the national policy formulation. Mackay Radio \& Tel. Co., 8 Radio Reg. 1174 (FCC 1955). This time the court of appeals affirmed. RCA Communications, Inc. v. FCC, 238 F.2d 24 (D.C. Cir. 1956). See also Mansfield Journal Co. (FM) v. FCC, 180 F.2d 28 (D.C. Cir. 1950).

2438 F.C.C. 1143 (1965).

$25 I d$. at 1149.

26 Id. at 1148-53. This was not the first time such allegations had been made against WLBT. See Lamar Life Ins. Co., 18 Radio Reg. 683 (FCC 1959).

27 See, e.g., Brown v. Board of Educ., 347 U.S. 483 (1954) ; Civil Rights Act of 1957, 71 Stat. 637, 42 U.S.C. \$1971 (1964) ; Civil Rights Act of 1964, 78 Stat. 243, 42 U.S.C. \$2000a (1964). 
while refusing equal time to those espousing the integrationist viewpoint, ${ }^{28}$ conduct which would seem to violate the Commission's fairness doctrine. ${ }^{20}$ Over and above any violation of the fairness doctrine, however, such conduct would seem to be a frustration of national policy. ${ }^{30}$ In spite of these allegations, the Commission granted a renewal of WLBT's license for a one year period, rather than the usual three, saying only that while serious questions were presented, it would be in the "public interest" to renew the license. 31 Nowhere in the opinion did the Commission discuss national policy; rather, it restricted itself to consideration of the fairness doctrine and to the question whether or not WLBT served the needs and interests of the community. ${ }^{32}$

Thus while the Commission made no findings on the United Church petition, ${ }^{33}$ it did make independent findings that the station did not afford equal time to integrationists. The frustration of national policy by the station is certainly a factor which the Commission should have discussed before granting a renewal. ${ }^{34}$ Moreover, in a case such as Lamar where

2838 F.C.C. at 1146-47.

The findings which the Commission deemed particularly significant were:

(i) In the Fall of 1962 , the station broadcast a series of editorials opposing the enrollment of James Meredith at the University of Mississippi.

(ii) In 1962-1963, WLBT broadcast a program series entitled "Comment" which . . discussed the issue of racial integration [from a segregationist's viewpoint] on various occasions.

(iii) In September of 1962 [WLBT] . . . presented a series of spot announcements paid for by the Jackson Citizens' Council. These spots showed newspaper clippings with the announcement that "You're seeing published proof that the Communists are behind the racial agitation now going on in Mississippi," and that "every white man and woman in Mississippi should be a Citizens' Council member" in order "to protect your family from these Communist-led integration attempts."

(iv) WLBT broadcast a program in which Tougaloo College, which is closely identified with the civil rights movement in Mississippi, was also accused of being Communist-infiltrated.

Id. at 1146-47. (Footnote omitted.)

20 See, e.g., Evening News Ass'n (WWJ), 6 Radio Reg. 283 (FCC 1950) ; New Broadcasting Co. (WLIB), 6 Radio Reg. 258 (FCC 1950). See generally Barron, The Federal Communications Commission's Fairness Doctrine: An Evaluation, 30 Geo. WASH. L. REV. 1 (1961).

$30 \mathrm{On}$ the other hand, a denial of equal time to segregationists might constitute a violation of the fairness doctrine, but still not be a frustration of national policy.

3138 F.C.C. at 1154.

32 Id. at 1154-55. While United Church framed its petition in these terms, id. at 1148-53, questions of national policy seem implicit therein. Moreover, even if such questions were not implicit, it would seem that an agency charged with finding the "public interest" should not disregard them. This should be distinguished from the situation where issues are not explicitly raised before a court, and the court should decide only the questions before it. See Mrsmrin \& Morris, ON LAw IN Courts 146 (1965).

33 This failure is itself an abuse of discretion. The Commission stated that the United Church petition raised serious "public interest" questions. 38 F.C.C. at 1154. To make no findings under these conditions seems to be clearly erroneous. See, e.g., SEC v. Chenery Corp., 318 U.S. 80 (1943) ; Hudson Valley Broadcasting Corp. v. FCC, 320 F.2d 723 (D.C. Cir. 1963) ; Missouri Broadcasting Corp. v. FCC, 94 F.2d 623 (D.C. Cir. 1937), cert. denied, 303 U.S. 655 (1938); 74 Stat. 891 (1960), 47 U.S.C. $\$ 309$ (e) (1964).

34 See FCC v. RCA Communications, Inc., 346 U.S. 86 (1953) ; McLean Trucking Co. v. United States, 321 U.S. 67 (1944). 
the national policy is clear and does not conflict with any other such policy, ${ }^{35}$ any frustration or attempted frustration of the national policy should result in denial of the application. The severe sanction of denial is justified by the nature of the offense committed by the station. Knowing violation ${ }^{36}$ of a clearly enunciated national policy is the most serious offense that a licensee qua licensee can commit. Surely a licensee who has so conducted himself has not acted in the "public interest." Thus if the Commission makes the permissible inference that one who has knowingly violated the "public interest" standard in the past would continue to do so in the future, ${ }^{37}$ WLBT's license could not be renewed. Moreover, given both the serious and repeated nature of WLBT's violations, perhaps the inference should not be merely permissible but rather mandatory. It is one thing to give a station another chance when it has failed to meet the "public interest" by playing too much "rock ' $n$ ' roll"; it is quite another matter to give the station another chance when it has repeatedly violated a national policy of critical importance.

Even if the inference is not mandatory and the FCC chooses not to make it, it is at least arguable that the licensee should be punished for past conduct. In FCC v. WOKO, Inc. ${ }^{38}$ the Supreme Court upheld the Commission's denial of a renewal where the licensee had made a misstatement in its application. No inference was made as to the ability of the licensee to serve the "public interest" in the future. Lamar presents a much stronger case for punitive action on the part of FCC than did WOKO.39

Action in accordance with the position that national policy, when unambiguous and of critical importance, is coterminous with "public interest"

35 Compare Lamar Life Broadcasting Co., 38 F.C.C. 1143 (1965), with McLean Trucking Co. v. United States, supra note 34, where there were conflicting policies. See text accompanying notes $16-17$ supra.

${ }^{36}$ It is impossible to imagine that WLBT did not know that there was a national policy favoring racial equality or that it did not know that it was violating this standard, at least in those instances in which the Commission found discrimination. See text accompanying notes $26-28$ supra.

37 See, e.g., Greater Kampeska Radio Corp. v. FCC, 108 F.2d 5 (D.C. Cir. 1939) ; Trinity Methodist Church, South v. Federal Radio Comm'n, 62 F.2d 850 (D.C. Cir. 1932), cert. denied, 288 U.S. 599 (1933); KFKB Broadcasting Ass'n v. Federal Radio Comm'n, 47 F.2d 670 (D.C. Cir. 1931); 48 Stat. 1085 (1934), as amended, 47 U.S.C. $\S 308$ (b) (1964).

38329 U.S. 223 (1946).

30 Cf. 48 Stat. 1086 (1952), as amended, 47 U.S.C. $\S 312$ (a) (1964).

There is no doubt that were the District of Columbia Circuit to set up a per se rule that any violation of a clearly. defined and critically important national policy would necessitate denial of an application for renewal, it would disregard the traditional doctrine of agency discretion which holds that the question whether or not a renewal would be in the "public interest" is to be made by the FCC after weighing all the evidence. FCC v. WOKO, Inc., 329 U.S. 223 (1946). This disregard seems necessary both because of the serious nature of the violation and the great impact which the use of mass media probably lent it.

An alternative solution would be for the FCC itself to formulate a per se rule whereby it would renew no licenses when it found facts which constitute a violation of an unambiguous and crucial national policy. This solution would involve no usurpation of agency discretion by the courts; but the FCC may not be willing to fogrmulate sụch ą rulẹ, 
would depart from the Commission's policy favoring renewal. ${ }^{40}$ This policy is predicated on a concern for the severe economic loss that would almost surely follow the denial of an application for renewal.41 It seems, however, that where a licensee chooses to violate such a national policy, he must be held willing to bear the risk of economic loss.

Although United Church has taken an appeal from the Commission's decision, ${ }^{42}$ it is doubtful whether, under present standards, that appeal will be heard on the merits. The right to appeal a decision and order of the FCC, which is analogous to having standing before the Commission, ${ }^{43}$ is provided by sections $402(\mathrm{~b})(2)$ and $402(\mathrm{~b})(6)$ of the Communications Act. The crux of these subsections is that "any person . . . aggrieved" by a Commission order has the right to appeal.44 In FCC v. Sanders Bros. Radio Station, ${ }^{45} \mathrm{Mr}$. Justice Roberts stated that potential economic injury is a sufficient ground to make one a "person aggrieved." ${ }^{46}$ While no

40 This policy is best exemplified by Thomas S. Lee Enterprises, Inc., 5 Radio Reg. 1179 (FCC 1949). In Lee, the Commission found a violation of its rules but admitted that it was reluctant to deny the application for renewal. Its reasoning was that such a denial is the equivalent of the "death sentence." Id. at 1200 .

41 See Churchill Tabernacle v. FCC, 160 F.2d 244, 248 (D.C. Cir. 1947). The economic loss would be caused by the licensee's being left with a used broadcasting station. Any prospective purchaser of the station's equipment would realize that the former licensee had no use for the equipment itself and would adjust his price accordingly.

42 Appeal docketed, No. 19,409, D.C. Cir., June 10, 1965.

43 A person has standing before the Commission when he is a "party in interest" as that phrase is used in $\$ 309$ (d) (1) of the Communications Act of 1934, 74 Stat. 890 (1960), 47 U.S.C. $\$ 309$ (d) (1) (1964). Section 309 (d) (1) reads, in part:

Any party in interest may file with the Commission a petition to deny any application ... The petition shall contain specific allegations of fact sufficient to show that the petitioner is a party in interest and that a grant of the application would be prima facie inconsistent with subsection (a) [which requires that in granting or renewing licenses the Commission must find that "the public interest, convenience, and necessity will be served"] of this section. . . .

4466 Stat. 718 (1952), 47 U.S.C. $\$ \S 402$ (b) (2), (6) (1964). More completely, these subsections provide:

(b) Appeals may be taken from decisions and orders of the Commission to the United States Court of Appeals for the District of Columbia in any of the following cases:

(2) By any applicant for the renewal or modification of any such instrument of authorization whose application is denied by the Commission.

-...

(6) By any other person who is aggrieved or whose interests are adversely affected by any order of the Commission granting or denying any application described in paragraphs (1)-(4) of this subsection.

15309 U.S. 470 (1940).

46 Id. at 477. This is basically the definition applied by the courts today. See, e.g. Southwestern Publishing Co. v. FCC, 243 F.2d 829 (D.C. Cir. 1957) ; Metropolitan Television Co. v. United States, 221 F.2d 879, 880 (D.C. Cir. 1955).

The Metropolitan case applies the definition in a roundabout way by saying that a "person aggrieved" is a "party in interest" as that term is used in $\$ 309$ of the act. 221 F.2d at 880 . Likelihood of economic injury has been held sufficient by the courts to make one a "party in interest." See, e.g., Interstate Broadcasting Co. v. FCC, 323 
subsequent case has held that likelihood of economic injury is a sine qua non to being a "person aggrieved," no one has ever been held a "person aggrieved" without such a showing. On the contrary, at least one case, National Anti-Vivisection Soc'y v. FCC, ${ }^{47}$ implies that such a showing is necessary. There the plaintiff applied to the district court for a writ of mandamus ordering the Commission either to conduct a hearing and revoke the license of WCIV, a Chicago station which had been broadcasting bullfights, or to issue a cease and desist order. In denying plaintiff's requests, Judge Robson stated that he doubted whether the society had standing to appeal under section 402 (b), noting that being a "vanguard" for interests which need protection does not, in itself, provide inclusion as a "person aggrieved." 48

The FCC's handling of the "party in interest" standard ${ }^{49}$ is strikingly similar to the courts' treatment of the "person aggrieved" standard. The Commission has gone one step further than the courts, however, and has held that likelihood of economic injury is not only sufficient but also necessary to make one a "party in interest." 50 In passing on the validity of the Commission's standard, the courts have agreed that a showing of potential economic injury is sufficient to make a person a "party in interest." 51 As in the "person aggrieved" cases, however, no court has ever found a person to be a "party in interest" without a showing of potential economic injury.

The legislative history of the act ${ }^{52}$ does not reveal the authority under which the courts and the Commission have so limited the two standards nor have the cases pointed out the reasons why they have done so. One reason might be to eliminate vexatious suits; another might be to prevent the "flood of litigation" that could arise if no limitations were placed on those having standing before the Commission and the right to appeal from

F.2d 797 (D.C. Cir. 1963) ; Interstate Broadcasting Co. v. United States, 286 F.2d 539 (D.C. Cir. 1960); Interstate Broadcasting Co. v. FCC, 285 F.2d 270 (D.C. Cir. 1960); Camden Radio, Inc. v. FCC, 220 F.2d 191 (D.C. Cir. 1954).

47234 F. Supp. 696 (N.D. I11. 1964).

$48 I d$. at 697.

49 See note 43 supra.

50 Gordon Broadcasting, Inc., 22 Radio Reg. 236 (FCC 1962) ; Cherry \& Webb Broadcasting Co., 10 Radio Reg. 181 (FCC 1954).

51 See, e.g., Interstate Broadcasting Co. v. FCC, 323 F.2d 797 (D.C. Cir. 1963) ; Interstate Broadcasting Co. v. United States, 286 F.2d 539 (D.C. Cir. 1960) ; Interstate Broadcasting Co. v. FCC, 285 F.2d 270 (D.C. Cir. 1960) ; Philco Corp. v. FCC, 257 F.2d 656 (D.C. Cir. 1958), cert. denied, 358 U.S. 946 (1959); Camden Radio, Inc. v. FCC, 220 F.2d 191 (D.C. Cir. 1954).

52 The legislative history of the "party in interest" standard, S. REP. No. 44, 82d Cong., 1st Sess. 8 (1951), does provide:

Fear has been expressed that use of "parties in interest" might make possible intervention into proceedings by a host of parties who have no legitimate interest but solely with the purpose of delaying license grants which should be made. The committee does not so construe the term "party in interest"; . . . "parties in interest" from an economic standpoint are defined by the Supreme Court decision in the Sanders case. . . .

See text accompanying notes 45-46 supra. Sanders, however, merely held that economic interest was sufficient to make one a "person aggrieved." Thus the legislative history is not dispositive. 
its decisions. Whatever the reason, the present application of the standards leaves persons with matters of critical importance to raise who will be heard only at the discretion of the FCC, ${ }^{53}$ and who have no right to appeal the Commission's decision. ${ }^{54}$

These standards are especially anomalous in light of the implication in the District of Columbia Circuit's recent opinion in James S. Rivers, Inc. (WJAZ) v. FCC ${ }^{55}$ that the court had a broader than usual scope of review in cases involving racial discrimination. The issue before the court in Rivers was the validity of the Commission's refusal to waive its "ten percent rule." 58 WJAZ, which was already authorized to operate an AM station during daytime hours, petitioned the FCC for authority to broadcast at night as well. The Commission denied the petition, stating that the proposed service would fail to reach the required ninety percent of the population in the service area. One of the reasons that WJAZ had urged in favor of waiver in this situation was that it was superior to the other stations in the community in serving the needs and interest of the Negroes in the service area. This contention was dismissed by the FCC. While the District of Columbia Circuit upheld the FCC's decision, the majority opinion implied and Chief Judge Bazelon explicitly stated in his concurring opinion that the court had a wider scope of review on this kind of question than in the more technical questions which the Commission must decide. ${ }^{57}$

Unlike the station in Rivers, however, most parties alleging racial inequality will not be able to show any likelihood of economic injury and thus under present standards would not have standing before the Commission nor the right to appeal from an FCC decision. If these standards are allowed to continue, the language of the court in Rivers concerning a broader scope of review in cases of racial discrimination would go for naught, as the court would only hear cases of alleged discrimination if the broadcaster chose to appeal the FCC decision. This is not likely if the Commission's disposition of the issue in Lamar is indicative of the treatment to be afforded those who deny racial equality.

Thus both the "party in interest" and "person aggrieved" standards are in need of revision. An exception should be carved into the economic injury test where the appellant would raise questions of national policy.

53 See text accompanying note 25 sipra.

54 See 68 YALE L.J. 783 (1959).

55351 F.2d 194 (D.C. Cir. 1965).

56 47 C.F.R. $\$ 73.28$ (d) (3) (1965). This rule provides that inability of proposed service to reach at least $90 \%$ of the population in a service area renders that proposed service unacceptable.

57 Chief Judge Bazelon stated that:

[O]n the question of discrimination in program content, the Commission's expertise is at least no greater than ours and no question of regulatory policy is involved in deciding whether or not the facts presented constitute discrimination. Also, we have no difficulty in analyzing the underlying facts as the court's close scrutiny of the record on this issue clearly demonstrates. It follows that our scope of review here is correspondingly wider Ithan in the more technical questions]....

351 F.2d at 198. 
While this exception could be limited somewhat by denying all subsequent petitions once one which adequately represents the interests of all petitioners is received, ${ }^{58}$ there is no doubt that a consequence of this revision would be an increase in the number of cases which the FCC and the District of Columbia Circuit would have to hear. Such a result would be justified, however, by a full airing of these crucial questions of national policy.

58 See generally WRIGHT, FEDERAL CouRTs $\$ 72$ (1963), which discusses the use of the class action in the federal courts. 